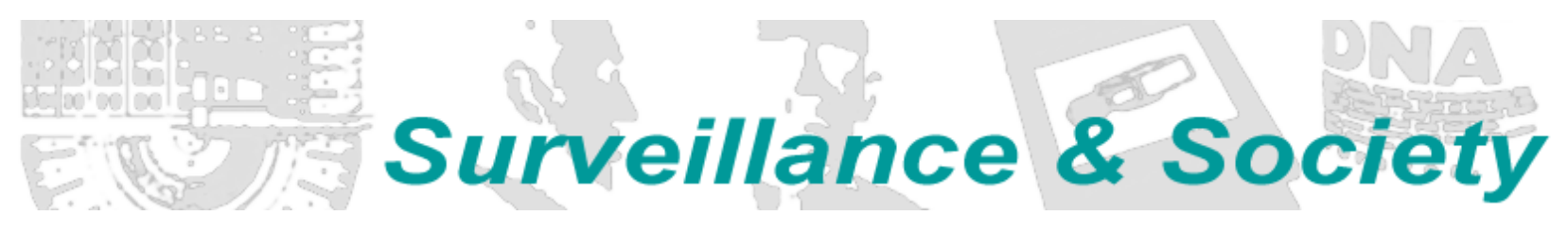

\begin{tabular}{l|l} 
& $\begin{array}{l}\text { Review of Sconce, Jeffrey. 2019. The Technical } \\
\text { Book }\end{array}$ \\
Review & $\begin{array}{l}\text { Duke Union: Electronics, Power, Insanity. Durham: } \\
433 \text { pp. US } \$ 29.95 . \text { Paperback. ISBN: } 9781478001065 .\end{array}$
\end{tabular}

\title{
Steven Kohm
}

University of Winnipeg, Canada

s.kohm@uwinnipeg.ca

Recently I was fitted with a new electronic prosthetic device that promised unparalleled integration between the self and an endless electronic network of information and entertainment delights. My new smartphone, I was told, had evolved well beyond the need for me to manually enter an alphanumeric password or even press my thumb against a fingerprint scanner. This new prosthetic device would use facial recognition software to simply know that it was me looking down upon it. Now my device seamlessly connects me to an electronic world with only a fleeting glance. As all of this was being explained to me in the clean, white, cult-like corporate store staffed with dozens of electronically tethered employees popping into and out of the conversation clutching their own prostheses, I mustered a wisecrack for the employee who was helping me at that moment. "What happens if I grow a beard?" I countered after rotating my head both clockwise and counterclockwise in front of my new device so it could capture my bemused face from all angles. "Don't worry," the salesperson replied without missing a beat, "it's always learning." And with that he was gone, replaced by another young person with earbuds and a tablet. As Sconce (2019) points out, the smartphone is rapidly becoming an essential and fully integrated prosthetic extension of the self, perhaps "making us all proto-cyborgs of one kind or another" (61). Moreover, my recent experience suggests that these commonplace devices are watching us by design as we find ourselves "chained to nearly ubiquitous networks of dispersed electronics and data" (61). Only a few years ago, one would have been dismissed as delusional for believing that a telephone was watching, monitoring, and learning about us in our most intimate moments or broadcasting information directly to us, yet we clearly live in an age where all of this is not only possible but certain. Sconce's sprawling archaeology of electronics, power, and insanity shifts the lens to examine not only the socially produced nature of insanity itself but also the long, complex cultural history of electronics and electricity and their links to matters of the mind, body, and soul. After reading this book, one could be forgiven for thinking that we are all, in fact, living in a delusion about the nature of technological integration and its connection to broader political and economic powers.

According to Sconce, the technical delusion, which is the subject of his analysis, is simply "a delusion about technology" - either an existing technology, like my smartphone, or something fantastical, such as "Venusian mind rays" (3). Sconce further argues that technical delusions spring from the "intersection of the deluded technically and the technically deluded" (4). The former refers to the nature of the delusion itself and the mindset of the person holding the belief and the latter refers to the medical-legal authority to deem one officially, or technically, insane. Sconce argues that technical delusions emerge in the nineteenth century along with electricity itself. He asserts that electronics can be thought of as "the politics of electricity, a channeling of this raw energy into conceptual and technical forms that index a history of power,

Kohm, Steven. 2020. Review of Sconce's The Technical Delusion: Electronics, Power, Insanity.

Surveillance \& Society 18(1): 130-132.

https://ojs.library.queensu.ca/index.php/surveillance-and-society/index | ISSN: 1477-7487

(c) The author(s), 2020 | Licensed to the Surveillance Studies Network under a Creative Commons

Attribution Non-Commercial No Derivatives license 
energetic and political" (4). Sconce's analysis places the politics of electronics alongside "the politics of psychosis" (7), arguing that the emergence of schizophrenia is "a new category produced by the modern psychiatric eye... literally a label" (8). The connection between modernity and insanity suggests that technical delusions may be socially produced reactions to the dizzying pace at which modern life and its associated electronic media have evolved since the nineteenth century, as well as an expression of semiotic and political power (18). Sconce treats technical delusions as "speculative discourses" about "biophysical, electrotechnical and socio-political models of "power" (19). His analysis asks not only about the potential for forms of power to be exercised through electronic means but also about the power of law and psychiatry to label beliefs pathological. Provocatively, he asks "Who is to say, and by what authority, where plausible technical affordances end and psychotic delusions begin?" (19). Gazing sideways at my smartphone, which, sensing my glance, leaps to life, I can only respond, "Who indeed?"

The Technical Delusion: Electronics, Power, Insanity is a dense read, extensively footnoted and rich with anecdotal detail drawn from historical literary accounts, news media reports, published psychiatric case notes, and even online archives of conspiracy theories proffered by those who most certainly are experiencing some form of technical delusion. Sconce provocatively moves from the present to early modernity and then back again, often tending toward some rather lengthy tangents, in the development of an analysis of the intersecting politics of electricity and psychosis. This book would appeal broadly to those interested in the history of psychiatry and power but perhaps less so to scholars interested in media studies more generally or those working in surveillance studies.

Sconce provides a fascinating discussion of the nature of technical delusions and the ways that modern psychiatry has attempted to identify, classify, and treat them. Distinguishing between delusions of influence and delusions of reference, Sconce demonstrates how media and electronics have been central in both. Importantly, Sconce argues that psychiatry has been at some pains to properly define delusion, reverting to rather indefensible definitions that focus less on content and more on the conviction with which the belief is held despite all evidence to the contrary. This begs interesting questions in our current age of social media and politically motivated cries of "fake news" and "alternative facts" that render truth a slippery concept. Am I suffering a delusion if I sympathize with conspiratorial websites and social media feeds? Is this evidence of "complex delusional systems of interactive paranoia" (30)? Sconce's discussion of the development and "seemingly inevitable rendezvous with the brain chip" (112) further challenges our assumptions about the nature of delusions in light of the convergence of the possible with the bizarre. While my recent experience with a new smartphone impregnated with artificial intelligence and surveillance capabilities certainly suggests the repositioning of the individual ego within a collective electronic network, the very real march towards the development of implanted digital technologies suggests a more literal transformation of the ego and a new frontier for the human soul: "bio-implants will eventually collapse such well-worn binaries as subject-object, private-public, interior-exterior, and real-virtual. Thought broadcasting and thought implantation, the signature curses of psychosis, will become deployable affordances as the classic psychotic dyad of self and Other dissolves into cybernetic collectivity. In effect, schizophrenia will be the new normal, and the Cartesian ego, the new insanity" (80).

The Technical Delusion offers a somewhat anecdotal socio-cultural analysis of the relative affinity between mental illness - schizophrenia characterized by delusions about electro-magnetic or electronic technologies, real or imagined-and shifting scientific, medical, and cultural developments and discourses about electronics, electricity, and psychiatry since the nineteenth century. Just as certain physical medical ailments appear to be linked to modern Western modes of life, Sconce's analysis suggests that technical delusions have become prominent over the past century. This begs important sociological questions. Did the rise of modern institutions of electronic media and broadcasting contribute to the rise of schizophrenia? Or did this simply provide a new focus for those predisposed? Sconce notes that delusions about the media "now constitute the single most common symptom among those deemed psychotic, especially those classified as 'schizophrenic' and 'paranoid"' (23). Provocatively, Sconce seems to suggest that perhaps those suffering from technical delusions may be merely reacting to the broad and insidious capabilities and powers of electronic media to penetrate and transform all areas of contemporary life. Drawing widely on 
psychoanalytic and postmodern theory and theorists, Sconce paints a dark picture of the future of humanity and the relationship between technological advancement and the self. He asserts that "unlike futurists who imagine humanity's ongoing prosthesis as benign and freely chosen augmentation, the psychotic appear more sensitive to the function of power, figurative and literal, in mediating these speculative-turnedoperational encounters between self and technology" (299). Sconce's view of the delusional and psychotic is certainly sympathetic and perhaps even romantic. Moreover, one might even wonder if we are already at a point where sanity and insanity have been reversed and the majority are now simply too delusional to recognize it. Perhaps I'll look to my smartphone for answers as I effortlessly connect to a cybernetic network of information and entertainment, earbuds implanted, my skull a virtual theatre.

The Technical Delusion is an interesting, certainly speculative, exploration of the interface between electronic technology, psychiatry, and the exercise of power. Sconce's historical breadth and anecdotal detail is both a strength and a weakness of the work. At times, the discussion seems to wander well off course and into, often very interesting but not well-connected, discussions of early quack science, electricity, magnetism, spiritualism, and other oddities of the nineteenth century before veering back toward more contemporary - or at least twentieth century - discussions of mediated technology and technical delusions. While certainly ambitious and meticulously executed, I found the wide-ranging and somewhat circuitous historical approach used in The Technical Delusion difficult to follow at times and perhaps a distraction from some genuinely fascinating analysis, particularly in the opening two chapters and the last part the book. The book has insightful and provocative things to say about contemporary issues of surveillance, technology, and the media, but it takes some determination to follow and connect the analytic threads. 